\title{
Student Entrepreneurs on University Campus in South Africa: Motivations, Challenges and Entrepreneurial Intention
}

\author{
Olawale Fatoki \\ Department of Business Management, Turfloop Campus, \\ University of Limpopo, Limpopo Province, South Africa \\ E-mail: Olawale.fatoki@ul.ac.za
}

\section{Doi:10.5901/mjss.2014.v5n16p100}

\begin{abstract}
The objective of the study was to investigate the factors that motivated student entrepreneurs to start business on the campus and the challenges that they face in running their businesses. In addition, the study examined the entrepreneurial intention of student entrepreneurs after leaving the university. The study used the qualitative research technique. In-depth interview method was used for data collection. The results indicated that students are pushed into entrepreneurship. Students are necessity entrepreneurs. Mixing school and business and financial constraints are major challenges. The results also indicated that the majority of student entrepreneurs intend to continue with the present business or start a new business after leaving the university.
\end{abstract}

Keywords: Student entrepreneurship, university campus, motivations, challenges, intention, South Africa

\section{Introduction}

According to Beeka and Rimmington (2011) and Buang (2011), entrepreneurship is one of the career options for youths and graduates. Sharma and Madan (2014) point out that governments and local communities worldwide have recognised that youth entrepreneurship is key to building prosperity and stimulating regional growth is fostering entrepreneurship among their people especially youth. Promoting youth entrepreneurship can help to reduce unemployment. Herrington et al. (2009) note that given the failure of the formal and public sector to absorb the growing number of job seekers in South Africa, increasing attention has focused on entrepreneurship and new firm creation and its potential for contributing to economic growth and job creation.

Youth and student entrepreneurship can help to improve the low rate of enterprise creation in South Africa. According to Turton and Herrington (2012), South Africa's Total Entrepreneurial Activity (TEA) rate decreased from 9.1\% in 2011 to $7.3 \%$ in 2012. South Africa's TEA is significantly below the average of efficiency-driven countries (14.3\%). the number of potential entrepreneurs is South Africa is below international standards. Potential entrepreneurs are defined by the Global Entrepreneurship Monitor (GEM) as those who perceive good business opportunities and believe that they have entrepreneurial capabilities. Potential entrepreneurs include students in high schools and universities. South Africa's rate of perceived opportunities is $36 \%$. This is below the average for efficiency-driven economies of $41 \%$. The country's rate for perceived capabilities is $40 \%$, below the average for of perceived opportunities efficiency-driven economies of $52 \%$ (Turton and Herrington 2012).

Rao (2014) points out that many of the successful entrepreneurs of today started their businesses on the university campus. These entrepreneurs turned their passions into businesses whilst earning their degrees. Successful business ventures are coming out of universities constantly. Campus Entrepreneurship explores the entrepreneurial opportunities and activities that exist in and around colleges and universities that students can explore (Campus entrepreneurship, 2014).

\section{Objective of the Study}

The objective of the study is to investigate the factors that motivated student entrepreneurs to start business on the campus and the challenges that they face in running their businesses. In addition, the study will examine the entrepreneurial intention of student entrepreneurs after leaving the university. 


\section{Literature Review}

\subsection{Definition of entrepreneurship}

Gedeon (2010) points out that the term entrepreneurship (or who is an entrepreneur) lacks a single unified and accepted definition. The literature is replete with criteria ranging from creativity and innovation to personal traits such as appearance and style (Fernald et al. 2005). According to Gedeon (2010), Cantillon, Turgot, Say and Schumpeter laid the foundations for the meaning of entrepreneurship. Cantillon defines the entrepreneur as someone who assumes the risk and may legitimately appropriate any profits. Turgot and Say point out that the entrepreneur obtains and organizes production factors to create value. Schumpeter (1934) relates entrepreneurship to innovation. The innovative activity of entrepreneurs feeds a creative "destruction process" by causing constant disturbances to an economic system in equilibrium, creating opportunities for economic rent. In adjusting to equilibrium, other innovations are spun-off and more entrepreneurs enter the economic system. McCleland (1961) asserts that entrepreneurial activity involves risk-taking, energetic activity, individual responsibility, money as a measure of results, anticipation of future possibilities, and organizational skills. Drucker (1985) notes that the entrepreneur always searches for change, responds to it, and exploits it as an opportunity. Innovation is the tool of entrepreneurship Rwigema and Venter (2004) define entrepreneurship as the process of conceptualising, organising, launching and through innovation, nurturing a business opportunity into a potentially high growth venture in a complex and unstable environment. Entrepreneurship is a vehicle to economic growth, success and prosperity. Herrington et al. (2009) point out that an entrepreneur is one that shifts economic resources out of an area of low productivity into an area of higher productivity and greater yield. An entrepreneur is one who organises, manages and assumes the risk of a business enterprise. According to Sathiabama (2010), entrepreneurship is a dynamic process of creating wealth by individuals or groups of individuals. The term small business owner is often used as a synonym for an entrepreneur (Aaltonen and Akola, 2014).

\subsection{Campus and student entrepreneurship}

Campus Entrepreneurship explores the entrepreneurial opportunities and activities that exist in and around colleges and universities (Campus entrepreneurship, 2014). Marchand and Sood (2014) remark that student entrepreneurs are not students merely attending entrepreneurial classes but conduct either a business on/near campus or lead a campus enterprise. According to the Vermont Agency for Education (2014), "student entrepreneurship is a program or activity that takes students through the process of learning what it takes to become a successful small business owner or manager. From a school-to-work standpoint, it represents preparing someone to understand all aspects of running a business and learning about being their own boss. Student entrepreneurship may take the form of school-based businesses that students help to set up and run, curricula that guides students through the process of creating business plans, working with local entrepreneurs and other community resources to plan and run enterprises, or any combination of these activities. Entrepreneurship offers students an interdisciplinary experience in understanding small business. Entrepreneurship may be undertaken on or off the school site".

\subsection{Motivations for entrepreneurship}

Zimmerman and Chu (2013) express that one recurring area of interest in the study of entrepreneurship is what motivates individuals to become entrepreneurs. According to Kirkwood (2009), individuals have various motivations for becoming an entrepreneur and there are four key drivers of entrepreneurial motivation according to the literature. These are (1) desire for independence (2) monetary motivation (3) motivation related to work such as unemployment, redundancy, a lack of job or career prospect and (4) family related motivations. Robichaud et al. (2001) find that the motivation of entrepreneurs falls into four distinct categories: (1) Extrinsic rewards (2) independence/autonomy (3) intrinsic rewards and (4|) family security. Swierczek and $\mathrm{Ha}$ (2003) find that SME owners in Vietnam are more motivated by challenge and achievement than the necessity for a career and economic security. Carter et al. (2003) reveal that the most popular motivating factor is the desire for an individual to achieve financial security. Chu et al. (2007) find that for Kenyan and Ghanaian entrepreneurs, increasing their income and creating jobs for themselves are the leading factors motivating them to become business owners. Benzing et al. (2009) find that the three most important motivators are to increase income, to have job security and to maintain personal freedom and independence.

Stefanović et al. (2011) point out that high levels of achievement motivation are consistent with the demands of entrepreneurial role. Achievement motivation appears to be an important characteristic for entrepreneurs. Krishna (2013) 
ascertains that motivational factors can be classified into internal and external factors. Internal factors are related to the personality of the entrepreneur and generate an inclination to adopt entrepreneurial activity. Internal factors include educational background, occupational experience, the desire to do something pioneering and innovative, the desire to be free and independent and family background. Entrepreneurial ambitions cannot fructify without a supporting environment. External factors provide support and give a spark to entrepreneurship. External factors include assistance from government and financial assistance from institutions.

Kirkwood (2009) and Charles and Gherman (2013) establish that motivations can be classified under push and pull factors. Push factors are those influences that push individuals toward entrepreneurship. Pull factors are those influences that pull people towards entrepreneurship. Push factors are characterised by personal or external factors. This category includes issues such as unemployment, redundancy, and a lack of job or career prospects. Pull factors are those that draw people to start businesses. This category includes opportunity identification. Kirkwood (2009) classifies the desire for independence and monetary motivation especially wealth creation as pull factors. Motivations to become an entrepreneur that relate to work are considered as push factors. Family-related motivations for becoming an entrepreneur are classified as push factors. This category includes a fit with and a desire for work-family balance. Islam (2012) and Charles and Gherman (2013) assert that push factors are those motivators characterised by personal or external factors. These include the need to support the family with additional income, difficulty in finding work, divorces, economic recession and job losses. Pull factors are those motivators related to opportunity and superior needs. These include independence, personal growth, self- fulfilment, social status, financial motivation and power. According to Bohla et al. (2006), push and pull factors can be compared to necessity-based entrepreneurship and opportunity-based entrepreneurship, Opportunity entrepreneurs are influenced by pull factors to start a business, while necessity entrepreneurs are affected by push factors.

\subsection{Barriers to entrepreneurship}

Fatoki and Garwe (2010) point out that the challenges to the growth of small businesses include lack of management skills, poor networking, high labour costs, crime and inaccessibility to finance. Lack of business skills is attributed to failure of business owned by young people (Papulova and Mokros, 2007). The need for capital is common to everyone who is self-employed (Casson, 2003). Elsenhardt and Martin (2000) use the Resource Based Theory to demonstrate the financing needs of an entrepreneur. Entrepreneurs need resources such as fixed assets and working capital to be able to achieve a competitive advantage in the market. Fatoki and Odeyemi (2010) observe that one of the causes of failure for small firms in South Africa is inaccessibility to external finance. Financing is needed for small firms to start and expand operations, develop new products, invest in new staff or production facilities. Perceived lack of support especially by government is another obstacle to the development of entrepreneurship in South Africa. South Africa government is committing a great deal of effort to support entrepreneurship Since most new entrepreneurs do not have the necessary capital to start a business, government support becomes very important. Unfortunately, most entrepreneurs are not aware of these government programmes, specifically designed to help them. There is little information on the types of financial products available to entrepreneurs as well as the procedure to apply for these products (Maas \& Herrington, 2006)

\subsection{Previous entrepreneurial experience and entrepreneurial intention}

According to McStay (2008), research has shown that an individual's past business experience influences their decisionmaking and business performance. Previous exposure to business, role models and networks are important reasons why individuals become entrepreneurs. Peterman and Kennedy (2003) find a positive relationship between prior work experience in a small business environment and attitudes toward entrepreneurship. Kolvereid (1996) points out that those with prior experience in entrepreneurial activities have higher entrepreneurial intention compared to those with no prior experience. According to Mazzarol et al. (1999) previous working experience can impact on entrepreneurial intention. People who have worked in the government sector are less likely to start a new business venture as compared to their counterparts with experience in private sector. Taylor and Thorpe (2004) explain the importance of networking in the entrepreneurial learning process. An integral part of the learning process is the complex network of relationships of the small firm owner-manager. Networking includes both work-related networks and social related networks. Networking improves access to resources and knowledge. Networking gained through previous work experience can positively impact on the entrepreneurial intention of students.

Ahmed et al. (2010) point out that students with entrepreneurial experience, whether self-experience, family 
experience or previous work experience are more inclined towards entrepreneurial career. This can be attributed to vigilance with the market and business and their knowledge regarding changing trends of market.

\title{
4. Research Methodology
}

The study was carried out at one of the campuses of one of the universities located in the Limpopo province of South Africa. The study used the qualitative research technique. According to Bricki and Green (2007), qualitative research is characterised by its aims, which relate to understanding some aspect of social life, and its methods which generate words, rather than numbers, as data for analysis. The study focused on students that manage small retail ventures in the university. An investigation by the researcher revealed that there are nine student entrepreneurs that are small retailers. The nine entrepreneurs were personally contacted by the researcher and the objectives of the study were explained to them. In-depth interview method was used for data collection. Guion et al. (2011) point out that in-depth interviews are a qualitative data collection technique that can be used for a variety of purposes. In-depth interviews are very suitable for situations in which the researcher wants to use open-ended questions to obtain information in depth from relatively few people. Interviews were conducted with the participants and recorded. Each interview took about 45 minutes and was done at the convenience of the participant. Opening questions focused on the departments of the participants, work experience before entering university and whether parents are involved or not involved in business. The participants were then asked questions on the motivations, challenges and entrepreneurial intention after leaving the university. The participants were encouraged to expand their answers through additional probing questions relating to the objectives of the study. The use of interview method for data collection is consistent with similar empirical studies on the motivation of entrepreneurs such as Kirkwood (2009) and Charles and Gherman (2013).

\section{Results and Discussions}

Nine student entrepreneurs were contacted and six participated in the study. The participants were made up of four females and two males. Two are from the Faculty of Agriculture, one from the Faculty of Management and three from the Faculty of Social Sciences. Three have parents that are involved in business and three have parents that are not involved in business. Four participants are in the final year and two in the second year of study.

\subsection{Motivation to start business}

The student entrepreneurs were asked about the motivation for starting their businesses on the campus.

\begin{abstract}
Participant 1: "I am from a poor family and I am the first born. I have three children and no parent. I started this business on the campus to support myself and my children. I come from a far township and need money for transport, food and family support"

Participant 2: "I started the business because I have financial problems. I am staying outside the campus and need to pay for my room and do photocopies that can help me with my studies"

Participant 3: "I had a business before entering the university. I accumulated trade debt and was blacklisted. I had an agreement with the creditor on how to pay back the trade debt. I also need money to take care of my children. You can say financial problems pushed me into business on the campus"

Participant 4: "I started my business on the campus because I tried getting a job outside but could not. I need money to take care of myself and my children"

Participant 5: I support myself financially. There is no support from anybody. I need to find a way to employ myself to survive"

Participant 6: I do not really have financial problems. I am doing business I enjoy selling things. I do not like to work for anybody. I just want to work for myself"
\end{abstract}

The results of the study indicate that the major reason why students start small business on the campus is to solve some financial challenges. The first five participants have financial challenges. Most of the participants have children to support apart from supporting themselves. One of the participants accumulated trade debt and must make repayments. One of the participants wants to be independent. In the context of the push-pull, the primary motivations for entrepreneurship by the first five participants can be classified as push factors. The sixth participant is motivated by desire for independence which is a pull factor. Kirkwood (2009) points out that family-related motivations for becoming an entrepreneur are classified as push factors. Motivations to become an entrepreneur that relate to work are also 
considered as push factors. Charles and Gherman (2013) assert that push factors are those motivators characterised by personal or external factors. These include the need to support the family with additional income, difficulty in finding work, divorces, economic recession and job losses. Pull factors are those motivators related to opportunity and superior needs. These include independence, personal growth, self- fulfilment, social status, financial motivation and power. The sixth participant is motivated by the desire for independence. According to Kirkwood (2009), a desire for independence and monetary motivation especially wealth creation as pull factors. In terms of necessity and opportunity entrepreneurship, the results indicate that the participants are necessity entrepreneurs. According to Bohla et al. (2006), push and pull factors can be compared to necessity-based entrepreneurship and opportunity-based entrepreneurship. Opportunity entrepreneurs are influenced by pull factors to start a business, while necessity entrepreneurs are affected by push factors. Block and Wagner (2010) point out that opportunity entrepreneurs are entrepreneurs who start a business in order to pursue an opportunity, while necessity entrepreneurship is more need-based. In addition, the results suggest that poverty is one of the push factors that motivate student to become entrepreneurs in South Africa. Oosthuizen (2008) points out that the level of poverty is very high in South Africa. The results are consistent with the findings of Ndirangu and Bosire (2004) that entrepreneurship is a survival strategy by students.

\title{
5.2 Barriers
}

The participants were asked about the barriers that they face in running and growing their businesses

\begin{abstract}
Participant 1 "it will be nice to have a shop to sell goods on the campus. I just stay anywhere on the campus and put out my goods. It is also difficult to mix school work with business and at times I have to miss lectures. I employ one person but I pay her R50 everyday she helps me. This is an additional cost and eats into my profit. I need financial assistance to buy more products and grow the business"

Participant 2: "the major problem is having someone to help me when I have classes. I need the support of the university to have a place that I can lock up when I go for lectures. I need more money and I don't have it to buy more stock"

Participant 3: "Difficult to mix lectures with business. Finance is constraint to move to something bigger"

Participant 4: "I want to expand my business but do not have the money. There are a lot of things one can sell on the campus with a good margin, but you need money"

Participant 5: "mixing school and business is quite difficult. You can see that I employ two people but I have to pay them. I want to expand the business but there is no additional capital"

Participant 6: "the major obstacle is getting money to expand this business. I want to have a shop outside the school"
\end{abstract}

The results indicate that business-school balance is one of the barriers faced by student entrepreneurs.

This has increased operating costs for some students as they need to employ assistants. In addition, most students do not have the financial resources to expand their businesses. According to Cassar (2004), all businesses require financial resources in order to start trading and to fund growth.

\subsection{Entrepreneurial intention}

The participants were asked about their entrepreneurial intention after they have completed their studies.

\begin{abstract}
Participant 1:"I will like to continue with business immediately I finish my studies. I will save some money, starting a business has stimulated me to be an entrepreneur"

Participant 2: "I will like to be an entrepreneur after finishing my studies but not immediately. Doing business on the campus has shown me that starting a business is a good thing. I may not get a job immediately after school. With a business, I will have something to do and take care of myself and family"

Participant 3: "I do not intend to continue with business after school. I want to and work gain experience. I might start a business later. Something that is big"

Participant 4: "my intention is to start a business immediately after school in town. Even if I get a job with a company or with government, I will still start a business. I enjoy doing business and I think that it is the future for me"

Participant 5: "I want to continue with business after study. Coming to school has opened my eyes to ideas. Sincerely, I do not want to work for anybody but myself after my studies"

Participant 6: "I will surely start a business after school. I do not enjoy working for other people. I want to work for me"
\end{abstract}

The results indicate that most of the participants intend to continue with the present business or start a new business after leaving the university. There is a high level of entrepreneurial intention by student entrepreneurs. McStay 
(2008) points out that an individual's past business experience influences their decision-making. Previous exposure to business is one of the important reasons why individuals become entrepreneurs. Peterman and Kennedy (2003) find a positive relationship between prior work experience in a small business environment and attitudes toward entrepreneurship. According to Ahmed et al. (2010), students with entrepreneurial experience, whether self-experience, family experience or previous work experience are more inclined towards entrepreneurial career.

\section{Conclusions}

Entrepreneurship is one of the career options for youths and graduates. The objective of the study was to investigate the factors that motivated student entrepreneurs to start business on the campus and the challenges that they face in running their businesses. In addition, the study examined the entrepreneurial intention of student entrepreneurs after leaving university. The results indicated that the major reason why students start small business on the campus is to solve some financial challenges. In the context of the push-pull motivating factors, the primary motivations for entrepreneurship by students are push factors. In terms of necessity and opportunity entrepreneurship, the results indicated that the participants are necessity entrepreneurs. In addition, the results indicated that business-school balance is one of the barriers faced by student entrepreneurs. This has increased operating costs for some students as they need to employ assistants. In addition, the majority of student entrepreneurs do not have the financial resources to expand their businesses. The results also indicated that most of the participants intend to continue with the present business or start a new business after leaving the university. This suggests that there is a high level of entrepreneurial intention by student entrepreneurs.

\section{Recommendations}

Government agencies that support entrepreneurship in South Africa such as the Small Enterprise Development Agency and the Small Enterprise Finance Agency should include student entrepreneurship in their strategic framework. Nonfinancial and financial support should be extended to student entrepreneurs in the universities. Student entrepreneurs in order to improve their entrepreneurial skills and competencies should join student groups that support entrepreneurship on the campus such as Enactus. Entrepreneurship education should be extended to all student entrepreneurs by the universities to improve their competencies. University should have a small business development office to assist student entrepreneurs. Business leaders should be willing to act as mentors to student entrepreneurs. There is the need for the university and student entrepreneurs to network with business leaders.

\section{Limitations and Areas for Further Study}

This study focused only on student entrepreneurs that are in the small retail business and can be extended to other business sectors that students participate in on the campus. In addition, the study was conducted in only one university. Thus, caution must be taken in interpreting the findings and in making generalisations. Data collection could be expanded to include a larger sample from other universities in South Africa.

\section{References}

Aaltonen Satu, Akola, Elisa (2014). Lack of trust: the main obstacle for immigrant entrepreneurship? [Online] Available: http://pyk2.aalto.fi/ncsb2012/Aaltonen.pdf (March 15, 2014)

Ahmed, I., Nawaz, M.M., Ahmad, Z., Shaukat, M.Z., Rehman, W., \& Ahmed, N. (2010). Determinants of Students' Entrepreneurial Career Intentions: Evidence from Business Graduates. European Journal of Social Sciences, (15(2): 14-22.

Beeka, B.H., \& Rimmington, M. (2011).Entrepreneurship as a career option for African youths. Journal of Development entrepreneurship, 16(1): 145-164.

Benzing, C., Chu, H. \& Kara, O. (2009). Entrepreneurs in Turkey: A factor analysis of motivations, success factors, and problems. Journal of Small Business Management, 47(1), 58-91.

Bhola, Reena, Verheul, Ingrid, Grilo, Isabel \& \& Thurik, Roy (2006), Explaining engagement levels of opportunity and necessity entrepreneurs. [Online] Available: http://repub.eur.nl/pub/9705/EIM20070208003_H200610.pdf (March 8, 2014)

Block, J., \& Wagner M. (2010). Necessity and Opportunity Entrepreneurs in Germany: Characteristics and Earnings Differentials. Schmalenbach Business Review, 62, 154-174.

Bricki, Nouria, Green, Judith (2007), A Guide to Using Qualitative Research Methodology. [Online] Available: http://msf.openrepository.com/msf/handle/10144/84230 (March 19, 2014) 
Buang, N.A. (2011). Entrepreneurship career paths of graduate entrepreneurs in Malaysia. Research Journal of Applied Business, 6(4): 282-289

Campus Entrepreneurship (2014), About campus entrepreneurship [Online] Available: http://campusentrepreneurship.wordpress.com labout-edu-entrepreneurship/ (March 19, 2014)

Carter, N. M., Gartner, W. B., Shaver, K. G., \& Gatewood, E. J. (2003). The career reasons of nascent entrepreneurs. Journal of Business Venturing, 18(1): 13-39.

Casson., M. (2003), Capital as a barrier to graduate entrepreneurship. [Online] Available: http://books.google.co.za/books?id =0sQCuLAf3u8C\&pg=PA167\&lpg=PA167\&dq=capital+as+a+barrier+to+gr (March 19, 2014)

Cassar., G (2004). The Financing of Business Start-Ups. Journal of Business Venturing, 19(2): 261-283.

Charles, V., \& Gherman T. (2013). Factors Influencing Peruvian Women to Become Entrepreneurs. World Applied Sciences Journal, 27 (10): 1345-1354

Chu, H. M., Benzing, C., \& McGee C. (2007). Ghanaian and Kenyan Entrepreneurs: A Comparative Analysis of Their Motivations, Success Characteristics, and Problems. Journal of Developmental Entrepreneurship, 12(3), 295-322.

Drucker P.F. (1985) Innovation and Entrepreneurship, London: Pan Books Ltd.

Elsenhardt, K.M, \& Martin J.A (2000). Dynamic capabilities: What are they? Strategic Management Journal, 21(1): 1105- 1121.

Fatoki, O., \& Garwe D. (2010). Obstacles to the growth of new SMEs in South Africa: A principal Component analysis approach. African Journal of Business Management, 4(5): 729-738.

Fatoki, O., \& Odeyemi A. (2010). Which New Small and Medium Enterprises in South Africa Have Access to Bank Credit? International Journal of Business and Management, 5(10): 128-136

Fernald, L.W., Solomon, G.T., \& Tarabishy A. (2005). A new paradigm: Entrepreneurial leadership. Southern Business Review, 30(2): 110.

Gedeon, S. (2010). What is Entrepreneurship? Entrepreneurial Practice Review, 1(3):16-35

Guion, Lisa, Diehl, David, \& McDonald, Debra (2014), Conducting an In-depth Interview [Online] Available: https://edis.ifas.ufl.edu/pdffiles/FY/FY39300.pdf (April 2, 2014)

Herrington, Mike, Kew, Jacqui, Kew, Penny (2009), Global Entrepreneurship Monitor, South African Report. From<http://www. gbs.nct.ac.za/gbswebb/userfiles/gemsouthafrica 2000pdf> (October 15, 2013).

Islam, S. (2012). Pull and push factors towards small entrepreneurship development in Bangladesh. Journal of Research in International Business Management, 2(3): 65-72

Kirkwood, J. (2009). Motivational factors in a push-pull theory of entrepreneurship. Gender in Management: An International Journal, 24(5): $346-364$

Kolvereid, L. (1996). Prediction of employment status choice intention. Entrepreneurship Theory and Practice, 21(1), 47-57.

Krishna. S.M (2013). Entrepreneurial Motivation: A Case Study of Small Scale entrepreneurs in Mekelle, Ethiopia. Journal of Business Management \& Social Science Research, 2(1): 1-6.

Maas, Gideon., \& Herrington, Mike. (2006), Global entrepreneurship monitor South African report. [Online] Available: http://www.gemconsortium.org/document.aspx?id756 (June 6, 2013)

Marchand, J., \& Sood, S (2014). The alchemy of student entrepreneurs: towards a model of entrepreneurial maturity. International Journal of Entrepreneurship and Innovation Management, Forthcoming

Mazzarol, T., Volery, T., Doss, N. \& Thein, V. (1999). Factors influencing small business start-ups. International Journal of Entrepreneurial Behaviour and Research, 5(2), 48-63.

McClelland, D. C. (1961). The achieving society. Princeton, NJ: Van Nostrand.

McStay, Dell, (2008), An investigation of undergraduate student self-employment intention and the impact of entrepreneurship education and previous entrepreneurial experience. [Online] Available: http://epublications.bond.edu.au/theses/18/ (January 15, 2014).

Ndirangu, M., \& Bosire J (2004). Student Entrepreneurship on Campus: A Survival Response or a Career Rehearsal? The Case of Egerton University Student Entrepreneurs Eastern Africa. Social Science Research Review, 20(1): 51-66

Oosthuizen, Morné, (2008), Estimating poverty lines for South Africa. [Online] Available: http://www.dsd.gov.za/index2.php ?option=com_docman\&task=doc_view\&gid=19\&ltemid (March 6, 2014)

Papulova, Zuzana, \& Mokros, Matej. (2007), Importance of managerial skills and knowledge in management of small entrepreneurs. [Online] Available: http://docs.google.com/gview?a=v\&q=cache:72zbAzSb_icJ:www.g casa.com/PDF/ (September 15, 2013).

Peterman, N.E. \& Kennedy, J. (2003) Enterprise education: Influencing students' perceptions of entrepreneurship. Entrepreneurship Theory and Practice, 28(2): 129-144

Rao, Dileep (2014), Should Universities Become Entrepreneurial Campuses? [Online] Available http://www.forbes.com/sites /dileeprao/2013/11/18/should-universities-become-entrepreneurial-campuses/\#./?\&_suid=1399281862602030538910424623633 (April 15, 2014).

Robichaud, Y., McGraw, E., \& Roger, A. (2001). Toward the Development of a Measuring Instrument for Entrepreneurial Motivation. Journal of Developmental Entrepreneurship, 6(1), 189-202.

Rwigema, H., \& Venter, R. (2004). Advanced entrepreneurship. Advanced Entrepreneurship. Cape Town: Oxford University Press Southern Africa.

Sathiabama, K. (2010), Rural women empowerment and entrepreneurship development. [Online] Available Available: http://www.microfinancegateway.org/ga (August 15, 2010].

Sharma, L., \& Madan, P (2014), Effect of individual factors on youth entrepreneurship - a study of Uttarakhand state, India. Journal of 
Global Entrepreneurship Research, 2(3): 1-17

Stefanovic, I., Rankovic, L., \& Prokic S (2011) Entrepreneurs' motivational factors: empirical evidence from Serbia. Serb Journal of Management, 6(11):73-84

Swierczek, F., \& Ha T.T (2003). Motivation, Entrepreneurship, and Performance of SMEs in Vietnam, Journal of Enterprising Culture, 11(1), 47-68.

Taylor, D., \& Thorpe, R. (2004) Entrepreneurial learning: A process of co-participation, Journal of Small Business and Enterprise Development, 11(2): 203-211.

Turton, Natasha, \& Herrington, Mike, (2013), Global Entrepreneurship Monitor South African 2012 Report. [Online]. Available: http://www.gemconsortium.org/docs/2801/gem-south-africa-2012-report (April 18, 2014)

Vermont Agency of Education (2014). Student entrepreneurship [Online]. Available http://education.vermont.gov/work-basedlearning/student-entrepreneurship (April 18, 2014)

Zimmerman, M.A \& Chu, H.N (2013). Motivation, Success, and Problems of Entrepreneurs in Venezuela. Journal of Management Policy and Practice, 14(2):76-90 